\title{
ポリア之ノポリブテニルとはく酸イミドと カルボン酸との非水溶媒中における相互作用*
}

\author{
渡辺治道** \\ Interaction of Polyaminopolybutenylsuccinimides with Carboxylic Acid \\ in Nonpolar Media \\ by Harumichi Watanabe
}

\begin{abstract}
Summary : An investigation was made on the interaction of polyaminopolybutenylsuccinimides with carboxylic acids by using the vapor pressure osmometer and the nuclear magnetic resonance spectroscopy.

The following results were obtained:

(1) Polyaminopolybutenylsuccinimides do not form micelle in hydrocarbons even with addition of carboxylic acids.

(2) Polyaminopolybutenylsuccinimides which have tertiary amino groups in their polar side chains do not interact with carboxylic acids.

(3) Polyaminopolybutenylsuccinimides which have primary or secondary amino groups in their polar side chains react with carboxylic acid, and then form ion pairs.

(4) These types of interaction mentioned above are similar to those of $n$-butylamine with carboxylic acid, and not those of surface active agents.
\end{abstract}

\section{1 緒 言}

無灰清浄分散鼡が低温スラッジに対して有効な理由の一つと して無灰清浄分散剤がスラッジプリカーサを可溶化することが あげられている。前報1)22で水およびメタノールをスラッジプ リカーサのモデル化合物とする可溶化機棈について報告した。 こはく酸イミド系清浄分散版がカルボン酸を可溶化することは 多くの研究者によって報告されている(3)-5)。しかしながら今ま で行なわれた研究はすへてて現象諭的な結果を報告しているにす ぎす，現在までこはく酸イミドは油中でミセルを形成している ものとして定性的な説明が行なわれてきた。

一方非水溶媒中に拄けるアミンとカルボン酸との反灾は，イ オン対の形成または水素結合錯体の形成として解析されてお り ${ }^{(3) 9), 1}$ 分子のアミンは 1 3 分子の有機酸と反応することが 知られている。

本報は蒸気圧オスモメーターおよびNMR を使用してこはく 酸イミド系清浄分散礼とカルボン酸との相互作用を検討したも のである。

\section{2 実験装置および方法}

\section{1 蒸気圧オスモメーターによる相互作用の研究方法}

蒸気圧オスモメーターは溶媒と溶液との蒸気圧の差を温度差 として観測して溶質の活量を求める装通である。1 種類の溶翼 を低濃度で溶存させた場合は測定結果から分子量を知ることが

*昭和 44 年 9 月 3 日受理 この報文を“こはく酸イミド系清浄分

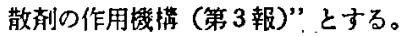

** 日本石油侏式会社中央技術研究所（川奇市夜光 2-3-2）

Central Technical Research Laboratory, Nippon Oil Co., Ltd. (2-3-2, Yako, Kawasaki)
できる。2 種類の溶質を溶存させて活量を測定し， 2 種類の溶質 間の相互作用を求める方法が Bruckenstein によって開発され たの)。彼はこの方法を Differential Vapor Pressure 法 (DVP 法）と名付けている。

Bruckenstein の解析方法は次のとおりである ${ }^{5)}$ 。2 種類の溶 盾 $\mathrm{B}, \mathrm{HX}$ が溶媒中で次のような反応を起したとする。

$$
\begin{aligned}
& \mathrm{B}+\mathrm{HX} \rightleftharpoons \frac{1}{m}(\mathrm{BHX})_{m} \\
& \frac{1}{m}(\mathrm{BHX})_{m}+\mathrm{HX} \rightleftharpoons \frac{1}{n}(\mathrm{BHX} \cdot \mathrm{HX})_{n}
\end{aligned}
$$

今 $\mathrm{B}$ を一定湝度として HX の添加量を变えていくものとす る。 $I$ および $R$ を次のように定義する。

$$
\begin{aligned}
& \mathrm{B} \text { と HX の混合物を溶質とする溶液の温度上昇， } \\
& I=\frac{\left(C_{\mathrm{B}}\right)_{t}=a[\mathrm{~mol} / l]}{\text { 㵚度 } a[\mathrm{~mol} / l] \text { のジベンジル溶液の温度上昇 }} \\
& R=\frac{\left(C_{\mathrm{HX}}\right)_{t}}{\left(C_{\mathrm{B}}\right)_{t}}
\end{aligned}
$$

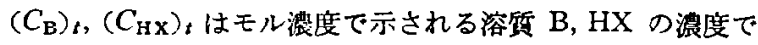
ある。Rの值は溶質 $\mathrm{HX}$ と溶質 B のモル比である。I の右辺 の分母はこのような希薄溶液中のジベンジルの活量係数が 1.0 であることを利用して基準を求める項である。溶質 Bが会合を 起さなければジベンジル溶液の温度上昇と溶質 Bだけを同モル 含む溶液の温度上䄯は等しい。Iの分子は $\mathrm{B}, \mathrm{HX}$ を含む溶液中 の実効溶質モル数に基つく温度上昇である。本報が問題とする カルボン酸-清净分散剂一溶媒系では B を清浄分散剂, HX をカ ルボン酸とする。清浄分散剤とカルボン酸との間にほとんど相 互作用が起らず，HX が単分子溶解している場合は Fig. 1 の $A G$ のらな直線関係が得られる。(1)，(2) の反応式の $m=1$, $n=0$ の時は ABC, $m=2, n=0$ の時は ADEF, $m=1, n=1$ の

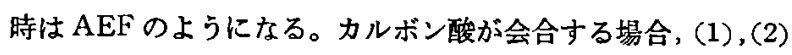


の反応に平衡がある場合 は直線のこう配が小にな る。たとえば $m=1, n=0$ の反応と $m=2, n=0$ の 両反応があり $m=2, n=0$ の反応は部分的にしか起 らないとすれば $\mathrm{ABC}$ の ようになる。カルボン酸 の添加によって清浄分散 剂がミセルを形成する場 合は HIJ のような曲線 が得られる。この場合は

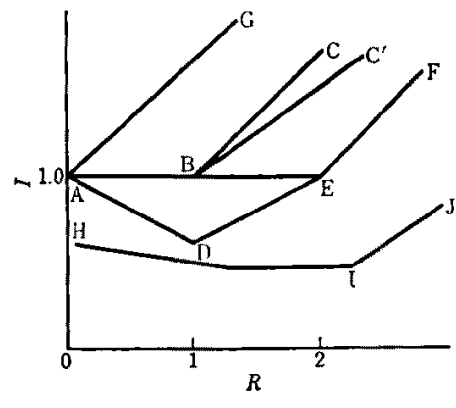

Fig. 1 Hypothetical Curves for for explanation) DVP Method (see text

少量のカルボン酸の添加により I の值が大幅に減少することが 特長である。この DVP 法が従来のガスクロマトグラフィーに よる気相濃度を測定する方法に比較してすぐれている点は分子 量の大きな溶質について実験の行なえること，強い相互作用に ついて解析できること，および測定系の温度が非常に精度高く 制御できることである。

DVP 法の測定法は次のとおりである。溶媒，消浄分散剂抢 よびカルボン酸を所定量含む溶液を調製し 12 時間以上静儖後，

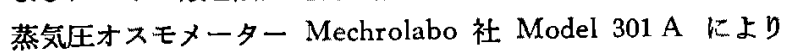
$\Delta: T$ を測定した。 $\Delta T$ の值は通常 2 分で安定となるが測定系に よっては 10〜20 分を要することもある。

そこで $\Delta T$ の值が 1 分間に 0.01 以上変化しなくなり安定し た時の值を測定值とした。この場合標準のジベンジル溶液の值 もその测定時の值によって補正してIの值を算出した。测定は 原則として 3 4 回測定してその平均値を測定値とした。DVP 法の測定は $\Delta T$ の值が小さい時および測定に長時間を要する時 ほど誤差が大きくなる。良好な条件下では100以, 悪々場合 は $10 \%$ 程度の精度となっている。

\subsection{NMR による相互作用の研究方法}

NMR の化学シフト $\delta$ は一般に次の式（3）であらわすこと ができる10

$$
\begin{aligned}
& \delta=\delta_{G}+\delta_{B}+\delta_{A}+\delta_{W}+\delta_{E}+\delta_{C} \\
& { }^{\delta_{G}}: \text { 现立した状热での化学シフト } \\
& \delta_{B} \text { : 溶媒の体積反磁性磁化率に起因するシフト } \\
& \delta_{A} \text { : 周囲の分子の磁化率の異方性によるシフト } \\
& \delta_{W} \text { : 隣接分子との間の Van der Waals 相互作用に } \\
& \text { よるシフト }
\end{aligned}
$$

したがって測定系を適当に選ふことによって目的とする溶質 プロトンの化学シフト 8 を $\delta_{G}$ と $\delta_{C}$ の項だけで決まるようにす れば，溶質間の分子間相互作用を観测することができる。今回 のこはく酸イミドーカルボン酸一溶媒系では分子間相互作用のう ち水素結合と水素交換が同時に観測されることが予見される。 水素交換の場合江両プロトンの荷重平均位置に吸収が観测 さ れ，水素結合の場合は低磁場シフトが観測される(1)ー10。

NMR の測定はVarian 社 A60A を使用して行なった。

\section{3 試料およひ試薬}

こはく酸イミド系清浄分散剤は前報》と同一物である。各こ
はく酸イミドの主成分は次のような化合物である。

こはく酸イミド-A

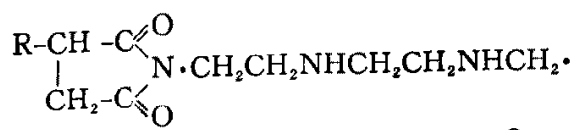<smiles>[R]C1C[C@H]2ON1CCN2OCCNCC</smiles>

$$
\begin{aligned}
& \text { こはく酸イミドーB }
\end{aligned}
$$

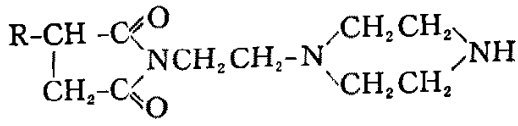

$$
\begin{aligned}
& \text { こはく酸イミドーC } \\
& \begin{array}{c}
\mathrm{R}-\mathrm{CH}-\mathrm{C} \\
! \\
\mathrm{CH}_{2}-\mathrm{C}^{\mathrm{O}} \mathrm{O}
\end{array} \mathrm{NCH}_{2} \mathrm{CH}_{2} \mathrm{CH}_{2} \mathrm{~N}^{\prime} \mathrm{CH}_{3}
\end{aligned}
$$

溶媒は次のようなものを使用した。

$$
\begin{aligned}
& n \text {-ヘプタン: Phillips 社製高純度品 } \\
& \text { ベン ゼン: 和光純藥工業 (株) 試獎特級 } \\
& \text { シクロヘキサン: 和光純㔨 吸収スペクトル用純溶媒 }
\end{aligned}
$$

酢酸は過マンガン酸カリウムを加えて蒸留したものを使用 し, 酪酸, カプリル酸は市販試真特級品をそのまま使用した。 nーブチルアミン,トリエチルアミンは蒸留精して使用した。 これらの有機酸, アミンの純度は中和滴定およびNMRにより 検定したがいずれも $98 \%$ 以上であった。

\section{3 結果および考察}

カプリル酸ーこはく酸イミドーnーヘプタン系の DVP 法の測定 結果を Fig. 2 に示した。こはく酸イミドの濃度は $2.0 \pm 0.1$ wt96 である。こはく酸イミド-Cの場合はカプリル酸とほとん どなんの相互作用も示さない。点線はカプリル酸だけの場合の 結果である。点線とこはく酸イミドーCの結果は実輸の誤差範 因内で一致する。カプリル酸の测定結果およびこはく酸イミ

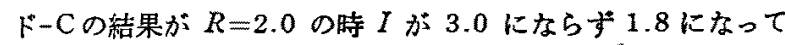
いるのはカプリル酸自身の会合のためで, $\mathrm{HX} \rightarrow \frac{1}{2}(\mathrm{HX})_{2}$ の会 合体が存在するためであると考えられる。

こはく酸イミドーBの場合の結果は Fig.1の解析法から次の 上うな反応が起っていると考えられる。非水溶媒とくに炭化水

$$
\begin{aligned}
& \mathrm{B}+\mathrm{HX} \rightleftharpoons \mathrm{BHX} \\
& \mathrm{BHX}+\mathrm{HX} \rightleftharpoons \mathrm{BH}(\mathrm{XHX})
\end{aligned}
$$

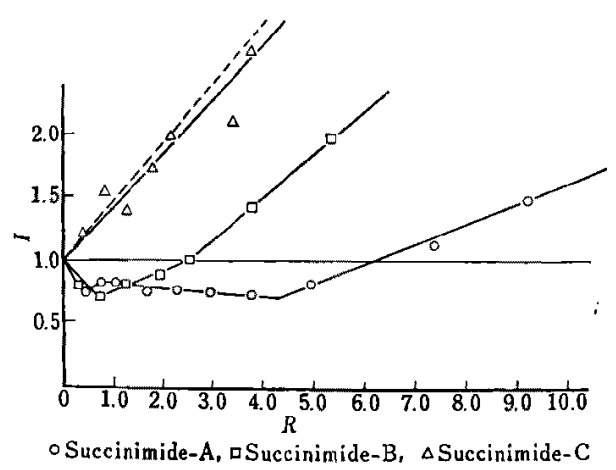

Fig. 2 DVP Data for Caprylic Acid and Succinimides in $n$-Heptane $\left(37^{\circ} \mathrm{C}\right)$ 


$$
\begin{aligned}
& \mathrm{BHX} \rightleftharpoons \frac{1}{2}(\mathrm{BHX})_{2} \\
& \mathrm{HX} \rightleftharpoons \frac{1}{2}(\mathrm{HX})_{2}
\end{aligned}
$$

素溶媒中の中和反応では式 (4)〜 (6) のよ5に反応生成物は各 種イオン対の生成として解析され，イオン対の解雄はごくわず かであると考えられるの 。式 (4)〜 (6) の反応のうち式 (4) の反応がまず起り，次いで式 (5)，(6) の反応が起ると考えら れる。I の値が 1.0 以下になっていることは式 (6) の反応の 存在を示している。これは式 (4)，(5) の反応では $I$ の值が 1.0 以下になることがないことから推論される。式 (5) の反応 の存在についてはこの結果からでははっきりしたことはわから ない。また $I$ の值が 0.7 前後で極小值を示した時の後の直線 のこう配がカプリル酸だけの場合よりも小であること，I の極 小傎 0.5 でなく 0.7 程度であることは式 (5)，(6) の反応が 起っていることとこれらの反応が完結しない平衡反応であるこ とを意味すると考えられる。

こはく酸イミド-Aの場合は 1 分子中に 3〜8個のアミノ基を 持つ化合物の混合物であり，Fig. 2 の曲線はさらに複雑な举動 を示す。こはく酸イミド-Bの場合の式 (4) に相当する反応は こはく酸イミド-Aの場合は式 (8) になる。しかしながら起っ

$$
\mathrm{B}+\boldsymbol{n} \cdot \mathrm{HX} \rightleftharpoons \mathrm{B} \cdot \boldsymbol{n H X}
$$

ている反応は基本的にはこはく酸イミド-B と同様と考えられ る。つまりまず式 (8) の反応が起り，次いで式 (5)，(6)に相 当する反応が起っている。こはく酸イミド-A の場合はこはく 酸イミド-B の場合に比校して $R>5.0$ 以上における直線のこ ら眍が小になる㑯向がさらにはっきり観測される。これは完結 しない式 (5)，(6) の反応の存在をより明らかに示しているむ のと考えられる。この場合も式 (6) の反応の存在は $I$ の值が 1.0 以下になることから確認されるが，式 (5) に相当する反応 についてはその存在ははっきりしない。

以上の解析は生成物がイオン対であるとしての解析である。 アンモニウム塩の存在することはこはく酸イミド-A およびこ はく酸イミド-B にカプリル酸を加えた時の $I R$ スペクトルの $3,600 \sim 2,000 \mathrm{~cm}^{-1}$ に幅広いアンモニウム塩の存在が認められ ることから確認される。一方式（4）（6）の反応はイオン対の 形成ではなく水素結合錯体の生成であるとしても説明が可能で ある。この点については NMR の測定結果のところで考察す る。

溶媒の種類を変えた場合の結果をこはく酸イミド-A一カプ リル酸系について Fig. 3 に示した。n-ヘプタンシクロヘキサ ンべンゼンと溶媒の溶解パラメーターが大きくなるほどより弱

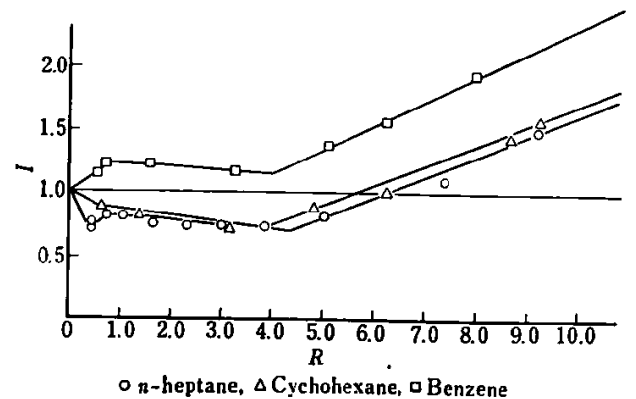

Fig. 3 DVP Data for Caprylic Acid and Succinimide$A$ in Various Solvent $\left(37^{\circ} \mathrm{C}\right)$
いイオン対が形成されるようになる。これは溶䕗と溶媒との相 互作用が強くなり，そのために溶質間の相互作用が弱くなるた めと考えられる。

DVP 法の測定結果は炭化水素中のカルボン酸とこはく酸イ ミドとの相互作用がカルボン酸とこはく酸イミドの側鎖のアミ ノ基によるものであることを明確に示している。またその相互 作用が基本的には各種イオン対の形成と推論できることを示す と同時に溶媒種, アミノ基の種類によりその挙動に変化のある ことが観測された。しかしながら DVP 法はこれらの相互作用 がどのような性質のるのであるかについては情報を提供してい ない。

カルボン酸は炭化水素溶媒中では水素結合により会合してお り，その会合状態はカルボン酸濃度によって変化する。カルボ ン酸プロトンのNMR スペクトルを観測するとカルボン酸プロ トンの化学シフトは浪度によって变化する。Fig. 5 に 3 種類 のカルボン酸プロトンの化学シフトを搌度を変えて測定した結 果を示した。カルボン酸の場合二量体の時にもっとも低磁場に プロトンの吸収が観测される゙3)。

Fig. 4 の系にこはく酸イミドを加えた結果が Fig. 5 であ る。

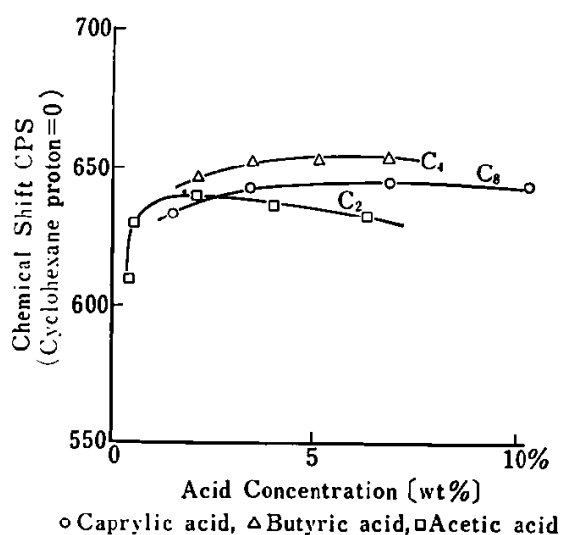

Fig. 4 The Change in Chemical Shift of the Acid Proton with Concentration of Acids

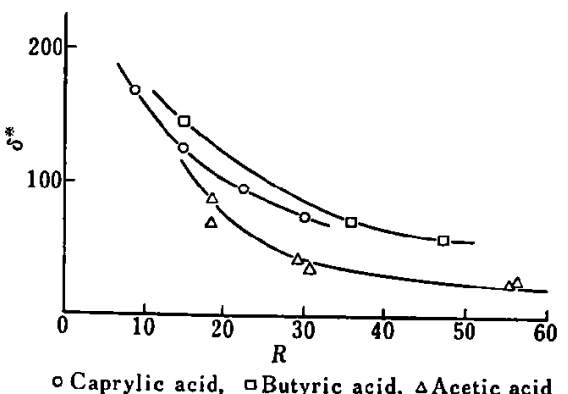

Fig. 5 The Chemical Shift of the Carboxylic Acid Proton in the Cyclohexane Solution Varying Quantities of Carboxylic Acid and Succinimide-A

図中の $\delta^{*}$ は次のような定義に基うく数值である。単位は CPS である。

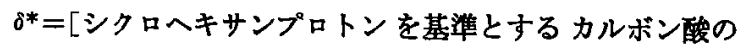
化学シフト(浱度 $a \mathrm{~mol} / l$ ) ]ー[シクロヘキサンプロトンを基準 とするこはく酸イミドーカルボン酸系のカルボン酸プロトンの 化学シフト(カルボン酸滣度 $a \mathrm{~mol} / l$ )] 
こはく酸イミドーA が加わることにより，カルボン酸プロト ンの化学シフトは高磁場にシフトする。こはく酸イミドーA は その檴造中にアミノ基プロトンを持つので, アミノ基プロトン [9.0 CPS に吸収がある。との間にプロトン交換が起り高磁場 にカルボン酸プロトンの化学シフトが移動するためと考えられ る。

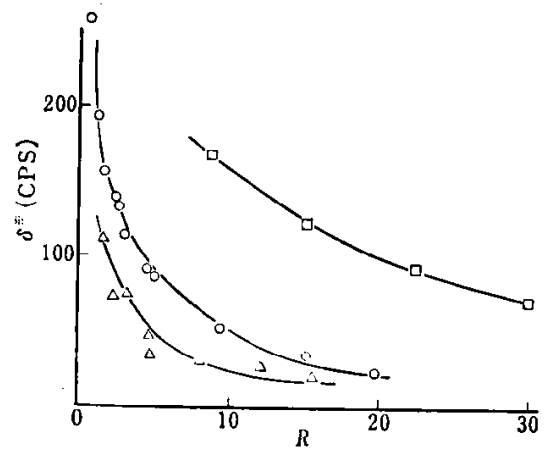

- n-Butylamine, a Succinimide-A $\Delta$ Succinimide- $B$

$\delta^{*}=$ (Chemical shift of caprylic acid) - (Chemical shift of caprylic acid-succinimide)

$R=$ Molar ratio of caprylic acid/succinimide or amine Fig. 6 Plots of $\delta^{*}$ Against $R$

カプリル酸に n-ブチルアミン，こはく酸イミドーAおよびこ はく酸イミド-Bを加えた場合の結果が Fig. 6 である。1 分子 中に多くのアミノ基プロトンを持つものほど大きな高磁場シフ トが観測されている。この結果をさらに定量的に解析するため 满軸の $R$ (カルボン酸モル数にはく酸イミドモル数)を $R^{\prime}$ (カ ルボキシル基のプロトン数/アミノ基のプロトン数)に変換した 結果が Fig.7 である。この場合，n-ブチルアミンはブロトン 数 2.0,こはく酸イミド-Aはプロトン数 10.0,こはく酸イミ

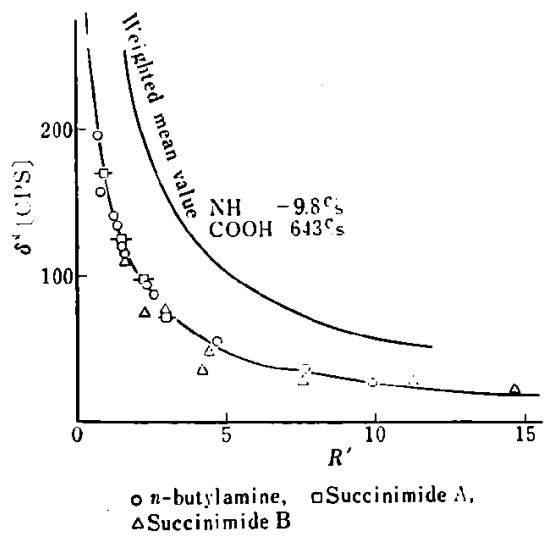

$\delta^{*}=($ Chemical shift of caprylic acid)-(Chemical shift of caprylic acid succinimide)

$R^{\prime}$ : Proton Ratio of $\mathrm{COOH} / \mathrm{N}-\mathrm{H}$

Fig. 7 Plot of $\delta^{*}$ Against $R^{\prime}$

脚注 1)これは次のような計算である。こはく酸イミドは分子量 2110 で\% $N$ が 6.8 であるから1分子中に $144 \mathrm{~g}$ の空菜原子を持 つ。これは 1 分子中に約 10 個の䇪素原子を持つことを意味 する。10 個のうち 2 個はイミド基使用されるはずである からフミノ基として存在する窒素原子は 8 個となる。こはく 酸イミドーA はての成分中にモノイトト，ジてミドを含むと とがIR スペクトルの結果から明らかなので，8個のアミノ 基のうち 2 個は第 1 級了ミ/基とすればフミ/基ブロトン の数は 10 個となる。
ドーBはプロトン数 1.0 として計算した。こはく酸イミド-Aは 他のこはく酸イミドと異なり混合物であるため分子式からプロ トン数を出すことができないので便宜的に $\%$ の 数值から大 略計算される 10.0 という数值を使用した䀧注 1)。Fig. 7 の結 果から次のような結諭が得られる。

(1) こはく酸イミドーカプリル酸系のプロトンの化学シフ トは N-H と会合状態の $\mathrm{COOH}$ との間に交換が起ったとして 計算した荷重平均化学シフトよりも低磁場に钼測される。

（2）こはく酸イミド-A，こはく酸イミド-B，および $n$-プ チルアミンの結果は同一曲線上にのる。これはこはく酸イミド 中のアミノ基は $n$-ブチルアミンのアミノ基と炭化水素中で同 じ挙動を示すことを意味する。

有機溶媒中のアミンーカルボン酸間の相互作用を検討した報 告によれば11),12)，このような結果は水素結合とプロトン交換が 其存して起っているものと説明されている。したがってこの場 合も荷重平均シフトからの低磁場人のずれは水素結合がイオン 対中のプロトンとアニオンの間に存在するとして説明できる。 しかしながらこの点については別の解釈も可能である。たとえ ば Fig. 7 の荷重平均位置の計算はアミノ基とカルボン䣲会合 体との間のプロトン交換として行なったが，これは啟密ではな い。正確にはカルボン酸会合体とイオン対中のアンモニウムイ オンとの荷重平均位膡として計算すべきである。残念ながらイ オン対中のアンモニウムイオンについての化学シフトの報告例 はない。Fig.8 の結果から逆に低磁場シフトは 100\% アンモ ニウムイオンに基ずくものとしてアンモニウムイオンの化学シ フトを計算すると $R=1 \sim 10$ の篹囲でシクロへキサンプロトン を基準として $490 \pm 10 \mathrm{CPS}$ にアンモニウムイオンの化学シフ トが存在することになる。この数值は水溶液中のアンモニウム イオンが 100〜250 CPS にブロードな吸収を持っことから考え て高すぎると考えられる。以上のような考察によりこはく酸イ ミド A, B とカプリル酸との間のイオン対中には水素結合をし ている部分があると考えるほうが妥当である。

こはく酸イミド中の N-H 基がnーブチルアミンのアミノ基と 同じ挙動を示すということは興味深い事実である。前報”で報 告したとおりこはく酸イミドは炭化水素溶媒中でミセルを形成 していない。またDVP 法の結果からここにカルボン酸が加わ りアンモニウム塩が形成されてもミセル形成が劲められない。 これらの事実をあわせて考えると，こはく酸イミドとカルボン 酸との相互作用は各種イオン対の形成と考えるべきで，いわゆ るミセルの存在によって起る可溶化現象ではない。

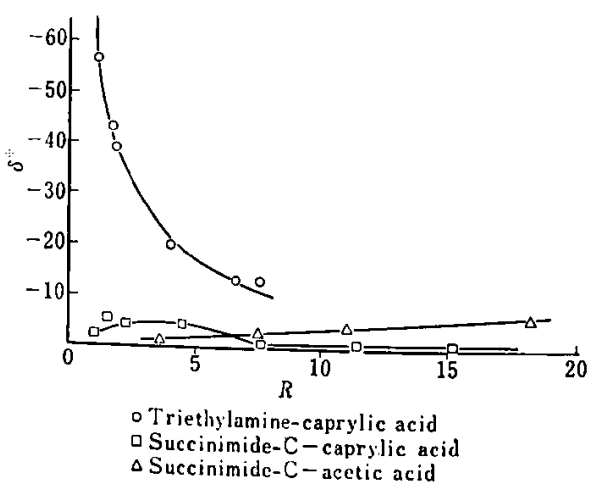

Fig. 8 Plot of $\delta^{*}$ Against $R$ 
こはく酸イミド-C とカルボン酸との NMR の湘定結果を Fig.8に示した。比較のためトリエチルアミンの結果をあわせ て示した。トリエチルアミンでは低磁場シフトが観測されるの に対してこはく酸イミドでは観測されない。この結果は Fig. 2 の DVP 法の結果に対応し，こはく酸イミド-C の側鎖にある 第 3 釉アミノ基はカルボン酸となんらの相互作用も行なってい ない。

\section{4 結 論}

こ注く酸イミド系清净分散削とカルボン酸との相互作用を蒸 気圧オスモメーターおよびNMR を使用して検討した結果, 次 のようなことが明らかになった。

（1）こはく酸イミドはカルボン酸が加わっでも炭化水素中 でミセルを形成しない。

（2）側銷に第 3 級アミノ基を一つだけ持つようなこはく酸 イミドはカルボン酸となんらの相互作用も行なわない。

（3）側鎖に第 1 級アミノ基または第 2 級アミノ基を持っこ
はく酸イミドはカルボン酸との間に各種イオン対を形成してカ ルボン酸の活量を減少させる。この相互作用は炭化水素中で $n$ ブチルアミンのような塩基が行なう相互作用と同じ性倎のむの で,ミセル形成に基つく可溶化作用ではない。

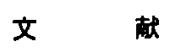

1) 渡辺, 石油誌, 13，(2), 112 (1970).

2) 渡辺, 石油婄, 13，(2), 116 (1970).

3) Groszek, A.J., ACS Preprint Div. Petrol. Chem., D-89 (1965).

4) Raney, M.W., ACS Preprint Div. Petrol. Chem., 13, (2), B 83 (1968).

5) Chev. Res. Corp. Report 667283 (1966).

6) Bruckenstein, S., Saito, A., J. Am.Chem. Soc., 87, 698(1965).

7) Barrow, G.M., Yerger, E.A., ibid., 76, 5211 (1954).

8) Barrow, G.M., Yerger, E.A., ibid., 17, 4474 (1955).

9) Barrow, G.M., Yerger, E.A., ibid., 11, 6204 (1955).

10) Schug, J.C., J. Phys. Chem., 70, 1816 (1966).

11) Isobe, T., Hazato, G., J. Chem. Phys., 28, 356 (1958).

12) Isobe, T., Hazato, G., ibid., 30, 1371 (1959).

13) Reeves, L.W., Trans. Faraday Soc., 55, 1684 (1959).

14）清水, 日化, 81, (7). 1025 (1960).

\section{国内ニュース}

石油連盟,西アフリカ原油輸送のコスト節減策検討へ＼cjkstart石 油業界ではナイジェリアなど西アフリカの原油輸入をすすめ るため, 近く石油連盟内に専門の委員会を設け, 西アフリカ 原油を安い運貨で輸入する方法を検討する。西アフリカ原油 はいお5分がきわめて少ない化め, 公害対策上石油業界で強 、関心を集めているが，中東産原油に比へ輸送コストがかさ み、これまでわが国ではほとんど輸入していない。新設する 委員会では日本, 欧州, 西アフリカを結ふ一種の三角輸送な どが検討される見通しである。いまのところ最も有効な方法 としてロイヤル・ダッチ・シェル，BP など西アフリカで原 油生産をしている国際资本と話し合い，中東一欧州一西アフ リカー日本一中東の経路でタンカーを配船する構想が浮かび あがっている。こうして中東原油を欧州に，西アフリカ原油 を日本に運べば，西アフリカと日本をピストン輸送するのに 比ベてタンカーを有効利用でき，かなり輸送コストを下げら れるという。

(日本程淡 12/21)

奵油, 快調な売れ行き本格的な灯油の販売シーズンに はいっているが, 石油業界では今シーズンの灯油の売れ行き はきわめて好調で 44 年度下期 (10 月〜45 年 3 月) の需要
は前年同期比䄪 3 割增の 1,000 万 $\mathrm{k} l$ の大台を越えるのは確 実と強気の見通しをたてている。これは石油ストーブの売れ 行きが好調であること，寒い冬が予想されることなどによ る。石油連盟がこのほどまとめた 44 年 11 月の灯油の販売 量は前年同期比 27.6 堌の $145 \mathrm{k} l$ 万と好調である。また， 石油業界では 12 月の販売量を前年同月比 6096 增の 252 万 $\mathrm{k} l$ と見込んでいる。各社は需要増を見込んでシーズン初め に灯油の備蓄をふやし增産体制をこったがこのよんでは 45 年 2 月末, 3 月末の元売り会社の合計在庫はいずれも 60 万 $\mathbf{k} l$ を割り，末端の販壳店では 2 月， 3 月ごろに一部の地 域で品不足も予想されるとしている。さらに年末から年始に 㜔ってくることが予想される寒波が，“異常寒波”となれば, 各地の品不足はかなり深刻化すると心配している。石油業界 では，普通のポータブル式の石油ストーブに比べ，灯油の使 用量が約 7 倍の大型のポット式が北海道, 東北地方などで急 速に出回っていること，生活様式の変化で石油ストーブが常 洔暖房として利用されだしたこと，セントラルヒーティング が本格的に普及し始めたこと，などを売机行き好調の要因と して指摘している。石油各社は需要が堅調であることを背景 に各社平均して 12 月に元売り仕切り価格を $1 \mathrm{k} l$ 当たり 1,000 円前後引き上げ， 9,500 円前後にした。各社とも 45 年 1 月にさらに值上げし，10,000 円以上にすることをもく ろんでいる。 